\title{
Polymorphism of Philaenus spumarius Linnaeus, 1758 (Hemiptera: Auchenorrhyncha: Aphrophoridae) in the Altai Mountains
}

\author{
Ekaterina Yu. Mayorova and Uliana V. Kolova* \\ Lobachevsky State University of Nizhny Novgorod \\ 23 Gagarin, Nizhny Novgorod, 603950, Russia
}

Received 22.05.2017, received in revised form 25.07.2017, accepted 30.08.2017, published online 21.05.2018

Information on polymorphism of the spittlebug Philaenus spumarius L. in five protected nature reservations of Altai Mountains (Katunsky State Nature Reserve, Tigireksky State Nature Reserve, Shavlinsky Nature Area, Katon-Karagaysky Natural Park, Saylyugemsky Natural Park) is presented. The total amount of collected P. spumarius was 549. Six colour forms have been registered in this region: typica, populi, flavicollis, leucocephala, leucophthalma, quadrimaculata, and, in addition, one unidentified form. The occurrence rate of different colour forms of the spittlebug was analyzed. The spatial and biotopical distribution of the registered forms was evaluated. The highest occurrence rate of P. spumarius is reported from shadowed, moderately humid habitats with high diversity of host plants, in particular, in forests (63\%), ruderal (47\%) and wetland (45\%) habitats. According to the results of comparative analysis of morph composition in the Altai and the Ural Mountains, it was concluded that such composition is typical for humid and highland regions of Palaearctic. The obtained data fully confirm the trends revealed in the previous research dedicated to polymorphism of P. spumarius: in humid regions morph composition is more meager and dark colour morphs are prevailing.

Keywords: Philaenus spumarius, polymorphism, spatial and biotopical distribution, Altai Mountains.

Citation: Mayorova E.Yu., Kolova U.V. Polymorphism of Philaenus spumarius Linnaeus, 1758 (Hemiptera: Auchenorrhyncha: Aphrophoridae) in the Altai Mountains. J. Sib. Fed. Univ. Biol., 2019, 12(4), 398-409. DOI: 10.17516/1997-1389-0050

(C) Siberian Federal University. All rights reserved

This work is licensed under a Creative Commons Attribution-NonCommercial 4.0 International License (CC BY-NC 4.0).

* Corresponding author E-mail address: u_kolova@mail.ru 


\title{
Полиморфизм Philaenus spumarius Linnaeus, 1758 (Hemiptera: Auchenorrhyncha: Aphrophoridae) на Алтае
}

\author{
Е.Ю. Майорова, У.В. Колова \\ Государственный Нижегородский университет \\ им. Н.А. Лобачевского \\ Россия, 603950, Нижний Новгород, пр. Гагарина, 23
}

\begin{abstract}
Приведены данные по полиморфизму Philaenus spuтаrius L. на пяти ООПТ Алтая: ГПЗ «Катунский», ГПЗ «Тигирекский», ГБЗ «Шавлинский», НП «Катон-Карагайский», НП «Сайлюгемский». Всего было рассмотрено 549 экземпляров Р. spuтагіus. Выделено 6 морф: typica, populi, flavicollis, leucocephala, leucophthalma, quadrimaculata, a также одна неидентифицированная морфа. Была проанализирована частота встречаемости особей с различными вариантами окраски. Оченены пространственное распределение и биотопическая приуроченность обнаруженных морф. Наибольшая встречаемость Р. spuтагіиs отмечена в затененных, умеренно увлажненных биотопах с большим разнообразием кормовых растений, 8 частности, лесных (63\%), рудеральных (47\%) и околоводных биотопах (45\%). По результатам сравнительного анализа состава морф, выявленного на Алтае, с таковым, описанным для Урала, отмечено, что данный состав характерен для гумидных и горных частей Палеарктики. Полученные данные полностью подтверждают выявленные в предыдущих работах по изучению полиморфизма пенницы тенденции - гумидные территории беднее по составу морф, и преобладающими здесь являются темные варианты окраски.
\end{abstract}

Ключевые слова: Philaепиs spuтагіиs, полиморфизм, пространственное распределение и биотопическая приуроченность, Алтай.

Цитирование: Майорова, Е.Ю. Полиморфизм Philaenus spumarius Linnaeus, 1758 (Hemiptera: Auchenorrhyncha: Aphrophoridae) на Алтае / Е.Ю. Майорова, У.В. Колова // Журн. Сиб. федер. ун-т. Биология, 2019. 12(4). С. 398-409. DOI: $10.17516 / 1997-1389-0050$

\section{Введение}

Полиморфизм - это существование в одном местообитании двух или более различающихся форм одного вида в такой пропорции, что редчайшая из них встречается чаще, чем если бы она поддерживалась лишь постоянными мутациями (Ford, 1940; цит. по: Береговой, 1971). Полиморфизм представляет собой источник эволюционных превращений внутрипопуляционных генетических вариаций в вариации, различающие популяции в пространстве или экологически, что составляет основу видообразования. Несмотря на то что в настоящее время популяции изучаются по разнообразнейшим признакам и различными методами, по-прежнему самыми удобными объектами для этой цели остаются популяции полиморфных видов.

Данная работа посвящена изучению полиморфизма пенницы Philaenus spumarius L. (Hemiptera: Auchenorrhyncha: Aphrophoridae) на Алтае. Этот вид - один из наиболее широко распространенных в Палеарктике, поэтому 
очень удобен для изучения географических аспектов полиморфизма. Подобные исследования проводились в ряде европейских стран, но данные отрывочны и неполны. Имеются сведения по качественному составу морф на Скандинавском полуострове (Halkka et al., 1967, 1976; Ossiannilsson, 1981), в Португалии (Quartau, Borges, 1997), Польше (Klimaszevski, Kosonocka, 1981), Турции (Yurtsever, 2000, 2004), Италии (Raatikainen, 1971; Halkka, 1987). В ряде работ рассмотрены генетические аспекты полиморфизма пенниц (Seabra et al., 2010; Lis et al., 2014; Rodrigues et al., 2014, 2016). В России полиморфизм пенницы достаточно полно изучен на Урале (Береговой, Аронов, 1969; Колова, 2009), в Нижегородской области (Колова, Бекетова, 2007), в Архангельской области (Пинежский заповедник) (Майорова, Колова, 2015) и на Дальнем Востоке (Колова, 2010). По данным В.Е. Берегового (1966) и Раатикайнена (Raatikainen, 1971), для пенницы в европейской части ареала выделяется 20 чистых морф и 4 смешанных. Те же морфы указываются для данного вида и из других частей Палеарктики (Береговой, Аронов, 1969; Колова, 2010), за исключением трех, описанных только из Италии (Raatikainen, 1971). В настоящей работе приведены данные по полиморфизму пенницы на Алтае, где подобные исследования никогда не проводились.

\section{Материалы и методы}

Для анализа использовались материалы, собранные в летние сезоны 2012-2016 гг. аспирантом кафедры ботаники и зоологии Нижегородского государственного университета им. Н.И. Лобачевского Е.Ю. Майоровой. Сборы за 2012 г. в заповеднике «Тигирекский» были предоставлены для анализа сотрудником заповедника Т.М. Круговой. Учеты вели методом кошения стандартным энтомологи- ческим сачком с подсчетом количества взмахов (Фасулати, 1971). Кошение проводилось с различных жизненных форм растений: с травяного покрова, кустарников и деревьев. Собранный материал хранится на кафедре ботаники и зоологии Нижегородского государственного университета им. И.Н. Лобачевского.

Обследовались пять особо охраняемых природных территорий (ООПТ) на Алтае (рис. 1):

1. Государственный природный биосферный заповедник «Катунский» (ГПЗ «Катунский») - с 23.07 по 5.08.2012 г.

2. Государственный природный заповедник «Тигирекский» (ГПЗ «Тигирекский») с 13.07 по 16.09.2012 г. (сборы Т.М. Круговой); с 12.08 по 21.08.2014 г. (сборы Е.Ю. Майоровой).

3. Государственный биологический заказник «Шавлинский» (ГБЗ «Шавлинский») с 7.08 по 21.08.2013 г.

4. Государственный национальный природный парк «Катон-Карагайский» (НП «Катон-Карагайский») - с 14.07 по 23.07.2015 г.

5. Национальный парк «Сайлюгемский» (НП «Сайлюгемский»): кластеры «Аргут» и «Сайлюгем» - с 17.08 по 29.08.2016 г.

Согласно физико-географическому районированию (Алпатьев и др., 1976) все обследованные территории относят к Алтайской области Алтае-Саянской горной страны. Территория Алтая, согласно схеме биогеографического районирования (Емельянов, 1974), относится к Евросибирской таежной (бореальной) области. На рис. 1 видно, что ГПЗ «Тигирекский» расположен в предгорьях Западного Алтая. НП «Катон-Карагайский» занимает самое южное положение, находясь на территории Восточного Казахстана. Остальные ООПТ расположены в Республике Алтай, занимая 


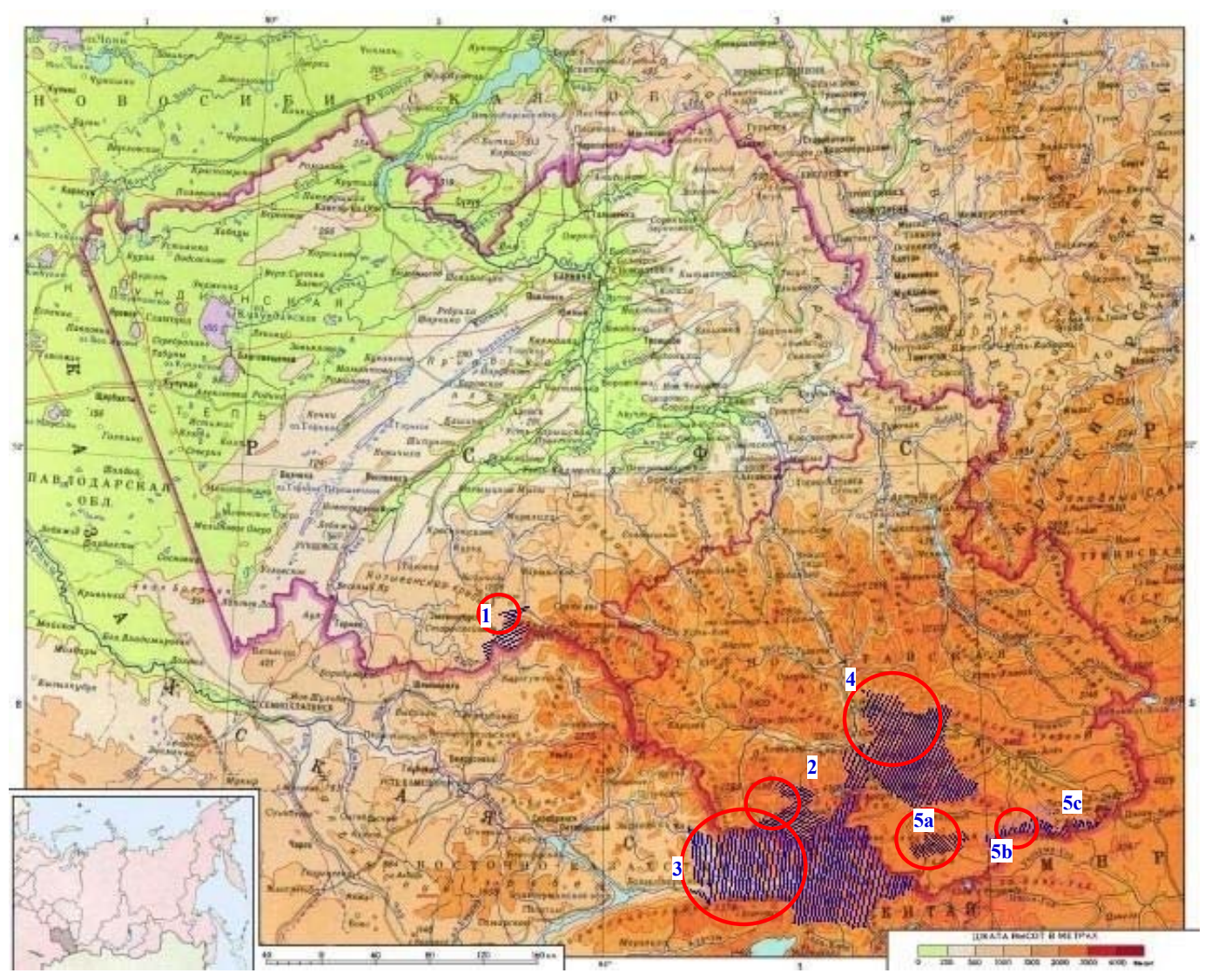

Рис. 1. Район проведения исследований и расположение обследованных ООПТ

Fig. 1. Investigated area and locations of studied natural reserves

Условные обозначения:

— граница административных регионов;

"III//. территория обследованных ООПТ:

1 - государственный природный заповедник «Тигирекский»;

2 - государственный природный биосферный заповедник «Катунский»;

3 - национальный парк «Катон-Карагайский»;

4 - региональный природный заказник «Шавлинский»;

5 - национальный парк «Сайлюгемский»: a) кластер «Аргут»; b) кластер «Сайлюгем»; с) кластер «Уландрык»;

локализация мест проведения учетов

центральные (ГПЗ «Катунский», заказник «Шавлинский», кластер «Аргут» НП «Сайлюгемский») и восточные (кластеры «Сайлюгем» и «Уландрык» НП «Сайлюгемский») районы. Они охватывают самые высокогорные части Алтайских гор, обладая в целом сходными, достаточно суровыми климатическими условиями. Для всех исследованных территорий характерно изменение облика и состава растительных сообществ с высотой, что можно описать в виде последовательности различных поясов растительности. Классификация поясов принята по Г.Н. Огуреевой (1980). В пределах отмеченных территорий обследовались пояса: степной, лесостепной, лесной, субальпийский, альпийско-тундровый. 


\section{Результаты}

Большинство сборов проводилось в лесостепном и лесном поясах, в диапазоне высот от 600 до 1700 м н.у.м. Как видно из табл. 1, именно в этом диапазоне высот был отмечен P. spumarius. Наибольшее количество - более половины всех особей (52 \%) зарегистрировано в ГПЗ «Катунский», а наибольшее богатство морф - в НП «КатонКарагайский» (5 из 6). Эти же показатели наименьшие в ГБЗ «Шавлинский» (соответственно $4 \%, 2$ из 6).

Для Алтая было выделено шесть морф пенницы обыкновенной (рис. 2): typica (typ), populi (pop), flavicollis (fla), leucocephala (lce), leucophthalma (lop), quadrimaculata (qua). Номенклатура морф принята по В.Е. Береговому (1966), далее по тексту используются сокращенные наименования. Один экземпляр пенницы обладал необычной окраской, не описанной ранее в работах В.Е. Берегового (1966) и М. Раатикайнена (Raatikainen, 1971). Это темная морфа с белой перевязью на вершине надкрылий, занимающей приблизительно одну треть длины (рис. 2). Описание новой морфы по одному экземпляру не представляется возможным, и в анализ данные по новой морфе не включены. Сведения о разнообразии морф $P$. spumarius на Алтае приведены в табл. 2. Сведения по ГПЗ «Тигирекский» за 2012 и 2014 гг. объединены.

Таблица 1. Количество особей (экз. / \%) и число выявленных морф P. spumarius на ООПТ Алтая

Table 1. Number of insects (number / \%) and number of registered morphs of $P$. spumarius in natural reservations of the Altai Mountains

\begin{tabular}{|l|c|c|c|c}
\hline \multicolumn{1}{c|}{ ООПт } & $\begin{array}{c}\text { Обследованные } \\
\text { высоты, м н.у.м. }\end{array}$ & $\begin{array}{c}\text { Высоты, где отмечался } P . \\
\text { spumarius, м н.у.м. }\end{array}$ & $\begin{array}{c}\text { Количество } \\
\text { P. spumarius }\end{array}$ & Число морф \\
\hline Катунский & $1300-2350$ & $1300-1800$ & $288 / 52$ & 4 \\
Сайлюгемский & $1200-2500$ & $1200-2100$ & $137 / 25$ & 3 \\
Катон-Карагайский & $700-2300$ & $700-1400$ & $74 / 14$ & 5 \\
Тигирекский & $550-1500$ & $550-1300$ & $28 * / 5$ & $4^{*}$ \\
Шавлинский & $1200-3100$ & $1200-2000$ & $21 / 4$ & 2 \\
Всего & $550-3100$ & $550-2100$ & $548^{*}$ & $6^{*}$ \\
\hline
\end{tabular}

* Значения указаны без учета неидентифицированной морфы.
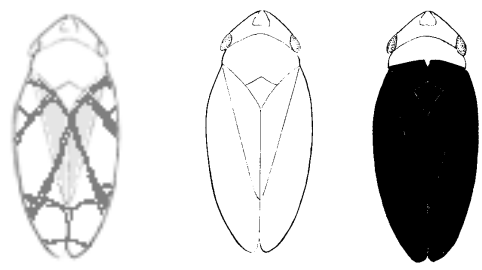

typica (typ) populi

leucoce-

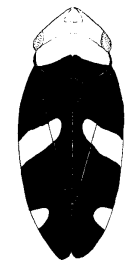

flavicollis

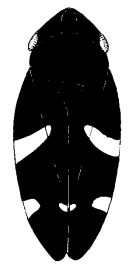

quadrimacu-

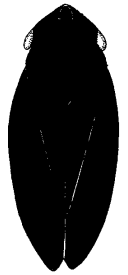

(fla) lata (qua)

\section{leucophthal-} ma (lop)

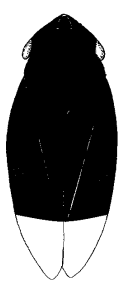

неопределенная морфа

Рис. 2. Полиморфизм P. spumarius Linnaeus, 1758 (Hemiptera: Auchenorrhyncha: Aphrophoridae) на Алтае

Fig. 2. Polymorphism of P. spumarius Linnaeus, 1758 (Hemiptera: Auchenorrhyncha: Aphrophoridae) in the Altai Mountains 
Таблица 2. Разнообразие морф P. spumarius на Алтае (экз. / \%)

Table 2. Diversity of morphs of P. spumarius in the Altai Mountains (number of insects / \%)

\begin{tabular}{|l|c|c|c|c|c|c|c|}
\hline \multirow{2}{*}{ ОоПт } & \multicolumn{7}{c|}{ Морфы } \\
\cline { 1 - 8 } & $t y p$ & $p o p$ & $l c e$ & $f l a$ & $q u a$ & $l o p$ & всего \\
\hline Катунский & $285 / 99$ & $1 / 0,3$ & $1 / 0,3$ & $1 / 0,3$ & 0 & 0 & $288 / 100$ \\
Сайлюгемский & $82 / 60$ & $54 / 39$ & $1 / 0,5$ & 0 & 0 & 0 & $137 / 100$ \\
Катон-Карагайский & $59 / 80$ & $9 / 12$ & $4 / 5$ & 0 & $1 / 1,5$ & $1 / 1,5$ & $74 / 100$ \\
Тигирекский & $21 / 72$ & 0 & $2 / 9$ & $2 / 9$ & $3 / 10$ & 0 & $28 * / 100$ \\
Шавлинский & $19 / 90$ & $2 / 10$ & 0 & 0 & 0 & 0 & $21 / 100$ \\
Всего & $466 / 85$ & $66 / 12$ & $8 / 1,5$ & $3 / 0,5$ & $4 / 0,7$ & $1 / 0,02$ & $548 * / 100$ \\
\hline
\end{tabular}

* Значения указаны без учета неидентифицированной морфы.

Самая обычная морфа, встречающаяся на всех территориях, - typ. Она представлена особями с различной интенсивностью окраски: от светлых до почти черных - с чередованием темных и светлых элементов рисунка на надкрыльях. На всех обследованных территориях именно эта морфа является самой многочисленной: 85 \% от общего числа особей. На втором месте - светлая морфа рор, встреченная на всех территориях, кроме ГПЗ «Тигирекский», и составляющая $12 \%$ от общего числа. Наибольшее количество пенниц, относящихся именно к этой морфе (39,5\%), отмечено только на территории НП «Сайлюгемский», где, соответственно, отмечено наименьшее (относительно всех территорий) количество typ (60\%).

Остальные морфы - темные, их четыре. На всех территориях, за исключением «Шавлинского» заказника, встречается единично $l c e-1,5 \%$. Остальные темные морфы fla, qua, $l o p$ встречены единично, за исключением также «Шавлинского» заказника и НП «Сайлюгемский». Обращает внимание разнообразие морф в ГПЗ «Тигирекский». Именно здесь оно наибольшее, поскольку процентное соотношение цветных морф почти одинаковое и составляет: lce - 9\%, fla-9\%, qua-10\%, при полном отсутствии рор.

\section{Обсуждение}

Объяснить полученные данные можно исходя из анализа биотопической приуроченности пенницы. В пределах ООПТ на Алтае обследовались группы биотопов с различным сочетанием фоновой растительности и микроклиматических условий. В пределах степного и лесостепного поясов выделены типы ксерофильных, относительно сухих биотопов: типчаково-ковыльные, разнотравнотипчаково-ковыльные, полынные, полыннозлаковые и петрофитные степи. Во всех поясах обследовались луга с разной степенью увлажненности: разнотравные, разнотравнозлаковые (суходольные, сенокосные, цветущие альпийские) и низкотравные злаковые (мелкозлаковники, субальпийские) с высокой продуваемостью. По совокупности условий луговые биотопы отнесены к мезофильным со средним уровнем увлажнения. Во всех поясах, за исключением субальпийского и альпийско-тундрового, обследовались гигрофильные, с избыточным увлажнением биотопы, представленные пойменными лугами, приречными зарослями и болотами. Здесь выделили два варианта сообществ, резко отличающиеся по встречаемости пенницы: 1) околоводное крупнотравье и 2) осоковые ассоциации. Наибольшее богатство биотопов 
характерно для лесного пояса, поскольку леса на Алтае представлены разными типами. В пределах ООПТ обследовались две группы лесных биотопов: 1) березняки и смешанные леса (с преобладанием мелколиственных пород); 2) хвойные леса, включающие светлохвойные (кедрач, лиственничник, редколесья, светлые поляны и опушки) и темнохвойные (черневая тайга, пихтарник, ельник). В лесах учеты проводились с травостоя и с деревьев. Учеты с деревьев и кустарников выделены в отдельную группу. Растительность деградированных пастбищных лугов, пустырей, сельских дворов и парков отнесена к рудеральным биотопам. Сводные данные приведены в табл. 3, в скобках дан процент встречаемости в данной группе биотопов.

Из данных, представленных в табл. 3, видно, что наибольшая встречаемость (63\%) P. spumarius отмечена в лесных биотопах, причем в тех лесах, которые условно отнесены нами к «светлым». Это смешанные леса и березняки. Здесь отмечается и наибольшее богатство морф (5 из 6). Именно в травостое под пологом мелколиственного леса создаются наиболее благоприятные условия для пенницы, поскольку микроклимат здесь характеризуется небольшой затененностью, умеренным увлажнением, низкой продуваемостью и богатством кормовых растений. Наши данные подтверждают классификацию А.Ф. Емельянова (1969), который относит пенницу к травяно-лесным видам.

На втором месте и по встречаемости и по богатству морф - рудеральные биотопы. Там сделано минимальное количество сборов (19) и почти в половине из них (47 \%) присутствовала пенница. Похожие данные получены и в Пинежском заповеднике (Майорова, Колова, 2015). Объяснить это можно, анализируя состав флоры рудеральных сообществ, в которых на долю 10 ведущих семейств растений приходится 77 \% видов (Радченко, 2005). В первую очередь это растения семейств

Таблица 3. Встречаемость и распределение морф P. spumarius по группам биотопов на Алтае

Table 3. Occurrence and distribution of morphs of P. spumarius among the studied habitats in the Altai Mountains

\begin{tabular}{|c|c|c|c|c|c|c|c|c|}
\hline \multirow{2}{*}{ Группа биотопов } & \multirow{2}{*}{$\begin{array}{c}\text { Общее число } \\
\text { учетов }\end{array}$} & \multirow{2}{*}{$\begin{array}{c}\text { Число (процент) } \\
\text { учетов, где отмечался } \\
\text { P. spumarius }\end{array}$} & \multicolumn{6}{|c|}{ Морфы } \\
\hline & & & typ & pop & lce & fla & $q u a$ & lop \\
\hline $\begin{array}{l}\text { Смешанные леса, } \\
\text { березняки }\end{array}$ & 19 & $12(63)$ & + & + & + & + & + & \\
\hline $\begin{array}{l}\text { Рудеральные } \\
\text { биотопы }\end{array}$ & 19 & $9(47)$ & + & & + & + & - & + \\
\hline $\begin{array}{l}\text { Околоводное } \\
\text { крупнотравье }\end{array}$ & 22 & $10(45)$ & + & + & - & - & - & - \\
\hline $\begin{array}{l}\text { Гигрофильные } \\
\text { осоковые }\end{array}$ & 31 & $3(10)$ & + & + & - & - & - & - \\
\hline Хвойные леса & 37 & $8(22)$ & + & + & + & - & - & - \\
\hline Луга & 53 & $9(17)$ & + & + & - & - & - & - \\
\hline Степные биотопы & 28 & $3(11)$ & + & + & - & - & - & - \\
\hline $\begin{array}{l}\text { Деревья, } \\
\text { кустарники }\end{array}$ & 110 & $7(6)$ & + & - & + & - & - & - \\
\hline Всего & 319 & $61(19)$ & & & & & & \\
\hline
\end{tabular}


Роасеае и Asteraceae, являющиеся наиболее предпочтительными для изучаемого вида в качестве кормовых растений (Емельянов, 1969).

Почти такая же высокая встречаемость (45 \%) пенницы в околоводных биотопах, представленных крупнотравьем. К крупнотравью отнесены сообщества растений, чьи побеги превышают 1 м длины и (или) имеют крупные листовые пластинки. В таких сообществах преобладают растения нескольких семейств: Umbelliferae, Asteraceae, Ranunculaceae, Rosaceae, Onagraceae, в том числе роды Filipendula, Chamerion, Delphinium и другие (Лащинский, 1999). По-видимому, условия здесь похожи на таковые под пологом леса и характеризуются повышенной увлажненностью, затененностью и наличием кормовых растений. Эти данные также подтверждают классификацию А.Ф. Емельянова (1969), который относит пенницу к влажнолуговым мезофилам. Сходными абиотическими условиями обладают и осоковые ассоциации, но там богатство видов меньше, а осока, по-видимому, не относится к кормовым растениям пенницы, потому и встречаемость меньше (10\%).

Существенно ниже встречаемость в хвойных лесах (22 \%). Это связано с сильной затененностью и, как следствие, меньшей долей в данном биотопе травянистых кормовых растений пенницы, замещенных черникой и брусникой.

Небольшая встречаемость пенницы в луговых биотопах (17 \%) объясняется тем, что луга в пределах степного и лесостепного поясов характеризовались недостаточным увлажнением, а в пределах субальпийского и альпийского поясов - суровостью условий и высокой продуваемостью. По причине недостаточного увлажнения и в степных биотопах встречаемость пенницы невелика (11 \%).
Наименьшая встречаемость пенницы отмечена на деревьях и кустарниках. Несмотря на то что общее число сделанных учетов максимальное, встречаемость пенницы - минимальна (6 \%). Сборы проводились с деревьев и кустарников в лесах, а также с отдельно стоящих форм в пределах всех поясов. Обследованы деревья родов: Salix, Populus, Betula (в том числе Betula humilis Schrank и Betula nana Linnaeus), Pinus, Picea, Larix, Abies, а также кустарники, среди которых роды: Rosa, Juniperus, Lonicera, Pentaphylloides, Caragana, Spiraea, Rubus, Ribes. По-видимому, большинство этих жизненных форм растений не являются кормовыми для пенницы, поскольку отмечено всего 7 экземпляров. Два экземпляра собрано с лиственницы (Larix sibirica Ledebour), два - с ив (Salix sp.), и по одному - с бобовых (Fabaceae), курильского чая (Pentaphylloides fruticosa (Linnaeus) O. Schwarz) и малины (Rubus sp.). Это подтверждает характеристику пенницы как полифага, предпочитающего травянистые растения (Ossiannilsson, 1981), несмотря на то, что многие авторы указывают некоторые кустарниковые и древесные формы в качестве кормовых (Halkka et al., 1967; Yurtsever, 2000).

Все цветные морфы собраны в рудеральных или лесных биотопах (березняк, ельник, смешанный лес). Незначительная представленность светлых морф объясняется тем, что большинство обследованных территорий характеризуются достаточно суровыми и холодными условиями, характерными для горных стран. В таких местах преобладают темные морфы. Это отражает общую экологическую закономерность, известную как правило Глогера (Одум, 1986): темноокрашенные особи приспособлены к большей аккумуляции тепла.

Сравнение полиморфной структуры популяций пенницы ООПТ Алтая с други- 
Таблица 4. Сравнение состава морф P. spumarius на Урале и Алтае.

Table 4. Comparison of the morph composition of P. spumarius in the Urals and the Altai Mountains

\begin{tabular}{|l|c|c|c|c|c|c|c|c|c|c|c|c|c|}
\hline \multirow{2}{*}{ Территории } & \multicolumn{10}{|c|}{ Морфы } \\
\cline { 2 - 14 } & typ & pop & qua & lop & fla & lce & mar & lat & ust & pra & tri & alb & gib \\
\hline ООПТ Алтая & + & + & + & + & + & + & - & - & - & - & - & - & - \\
Урал & + & + & + & + & + & + & + & + & + & + & + & + & + \\
\hline
\end{tabular}

ми изученными в этом отношении, похожими по условиям близлежащими регионами, в первую очередь с Уралом, позволяет судить, что состав морф пенницы на Алтае существенно беднее. Из табл. 4 видно, что из 13 морф, отмеченных на Урале, на исследуемых территориях выявлено только шесть. Вероятно, это связано с недостаточной изученностью Алтая, а также с компактностью положения Алтайских гор, по сравнению с Уральскими горами, простирающимися с севера на юг и с выраженной широтной зональностью.

Полученные данные полностью подтверждают выявленные в предыдущих работах по изучению полиморфизма пенницы тенденции - гумидные территории беднее по составу морф, и преобладающими здесь являются темные варианты окраски.

\section{Заключение}

В данной работе впервые приведены данные по полиморфному составу популя- ций P. spumarius на пяти ООПТ Алтая. Выделено шесть морф: typica, populi, flavicollis, leucocephala, leucophthalma, quadrimaculata, а также одна неидентифицированная морфа. При этом морфы typica и рорuli распространены практически на всех исследованных территориях, встречаемость прочих морф единична. Анализ биотопической приуроченности показал, что наибольшая встречаемость $P$. spumarius отмечена в затененных, умеренно увлажненных биотопах с большим разнообразием кормовых растений, в частности, лесных, рудеральных и околоводных. По результатам сравнительного анализа состава морф, выявленного на Алтае, с таковым, описанным для Урала, можно заключить, что данный состав, по-видимому, характерен для гумидных и горных частей Палеарктики. Для подтверждения полученных выводов в отношении частоты встречаемости различных морф работа может быть продолжена в направлении филогенетического анализа.

\section{Благодарность / Acknowledgement}

Авторы выражают благодарность Т.М. Круговой (Барнаул, ГПЗ «Тигирекский») за предоставленный для обработки материал.

The authors are grateful to T.M. Krugova (SNR Tigirekskiy, Barnaul) for collecting the samples.

\section{Список литературы / References}

Алпатьев А.М., Архангельский А.М., Подоплелов Н.Я., Степанов А.Я. (1976) Физическая география СССР (азиатская часть). М., Высшая школа, 360 с. [Alpatyev A.M., Arkhangelsky A.M.,

$$
-406-
$$


Podoplelov N.Ya., Stepanov A.Ya. (1976) Physical geography of the Soviet Union (Asia). Moscow, Vysshaya Shkola, 360 p. (in Russian)]

Береговой В.Е. (1966) Изменчивость природных популяций пенницы обыкновенной (Philaenus spumarius L.). Генетика, 11: 134-143 [Beregovoy V.E. (1966) Variability of natural populations of meadow spittlebug (Philaenus spumarius L.). Genetics [Genetika], 11: 134-143 (in Russian)]

Береговой В.Е. (1971) Исследование полиморфизма как путь познания хронологической структуры вида. Журнал общей биологии, 32(2): 143-151 [Beregovoy V.E. (1971) Study of polymorphism as a way to study chronological structure of a species. Journal of General Biology [Zhurnal obshchej biologii], 32(2): 143-151 (in Russian)]

Береговой В.Е., Аронов Л.Л. (1969) Некоторые данные по экологии обыкновенной пенницы (Philaenus spumarius L.) на Среднем Урале. Научные доклады высшей школь, Биологические науки, 8: 10-11 [Beregovoy V.E., Aronov L.L. (1969) Data on ecology of meadow spittlebug (Philaenus spumarius L.) in the Middle Urals. Scientific Reports of Higher School, Biological Sciences [Nauchnye doklady vysshej shkoly, Biologicheskie nauki], 8: 10-11 (in Russian)]

Емельянов А.Ф. (1969) Цикадовые (Homoptera, Auchenorrhyncha). Биокомплексныле исследования в Казахстане. Ч. 1. Растительные сообщества и животное население степей и пустынь Центрального Казахстана. Л., Наука, с. 358-381 [Emeljanov A.F. (1969) Cicadas (Homoptera, Auchenorrhyncha). Complex biological research in Kazakhstan. Part 1. Plant associations and animal population of steppes and deserts of Central Kazakhstan. Leningrad, Nauka, p. 358-381 (in Russian)]

Емельянов А.Ф. (1974) Предложения по классификации и номенклатуре ареалов. Энтомологическое обозрение, 53(3): 497-522 [Emeljanov A.F. (1974) Recommendations on classification and identification of biogeographical ranges. Entomological Review [Entomologicheskoe obozrenie], 53(3): 358-381 (in Russian)]

Колова У.В. (2009) Полиморфизм пенницы Philaenus spumarius L. на Урале. Известия Челябинского научного иентра, 4 (46): 38-42 [Kolova U.V. (2009) Polymorphism of the spittlebug Philaenus spumarius L. in Ural Mountains. News of Chelyabinsk Scientific Center [Izvestiya Chelyabinskogo nauchnogo centra], 4 (46): 38-42 (in Russian)]

Колова У.В. (2010) Полиморфизм пенницы Philaenus spumarius L. на Дальнем Востоке. Вестник Нижегородского университета им. Н.И. Лобачевского, 2 (2): 402-406 [Kolova U.V. (2010) Polymorphism of the spittlebug Philaenus spumarius L. in Far East. News of Lobachevsky State University of Nizhny Novgorod [Vestnik Nizhegorodskogo universiteta im N.I. Lobachevskogo], 2 (2): 402-406 (in Russian)]

Колова У.В., Бекетова Ю.А. (2007) Полиморфизм цикады Philaenus spumarius L. (Homoptera, Cicadinea) в Нижегородской области. Зоологические исследования регионов России и сопредельных территорий, с. 26-29 [Kolova U.V., Beketova Y.A. (2007) Polymorphism of the spittlebug Philaenus spumarius L. (Homoptera, Cicadinea) in Nizhny Novgorod Region. Zoological Research in Russia and adjacent regions, p. 26-29 (in Russian)]

Лащинский Н.Н. (1999) Эколого-географический анализ высокотравных видов флоры Сибири. Krylovia. Сибирский ботанический журнал, 1(1): 70-79 [Lashchinsky N.N. (1999) Ecological and geographical analysis of tall-grass species in Siberian flora. Krylovia. Siberian Botanical Journal [Krylovia. Sibirskij botanicheskij zhurnal], 1(1): 70-79 (in Russian)]

$$
-407-
$$


Майорова Е.Ю., Колова У.В. (2015) Полиморфизм Philaenus spumarius (Linnaeus, 1758) (Homoptera, Cicadinea, Aphrophoridae) в Пинежском заповеднике. Евразиатский энтомологический журнал, 14(1): 50-53 [Mayorova E.Yu., Kolova U.V. (2015) Polymorphism of Philaenus spumarius Linnaeus, 1758 (Homoptera, Cicadinea, Aphrophoridae), in Pinezhsky Reserve. Euroasian Entomological Journal [Evraziatskij ehntomologicheskij zhurnal], 14(1): 50-53 (in Russian)]

Огуреева Г.Н. (1980) Ботаническая география Алтая. М., Наука, 192 с. [Ogureeva G.N. (1980) Botanical geography of Altai Mountains. Moscow, Nauka, 192 p. (in Russian)]

Одум Ю. (1986) Экология. T. 1. М., Мир, 328 с. [Odum Е. (1986) Ecology. Vol. 1. Moscow, Mir, 328 p. (in Russian)]

Радченко Т.А. (2005) Естественная флора травянистых растений центральных районов Екатеринбурга. Экология фундаментальная и прикладная, с. 279 [Radchenko T.A. (1980) Natural flora of gasses in central districts of Yekaterinburg-City. Fundamental and applied ecology, p. 279 (in Russian)]

Фасулати К.К. (1971) Полевое изучение наземных беспозвоночных. М., Высшая школа, 424 с. [Fasulati K.K. (1971) Field studies of terrestrial invertebrates. Moscow, Vysshaya shkola, 424 p. (in Russian)]

Halkka O. (1987) Colour morphs of Philaenus spumarius are ecomorphs and are dissimilary distributed in different of the habitat. Proc. 6-th Auchen. Meeting, p. 347-358

Halkka O., Raatikainen M., Vasarainen A., Heinonen L. (1967) Ecology and ecological genetics of Philaenus spumarius (L.) (Homoptera). Annales Zoologici Fennici, 4: 3-18

Halkka O., Raatikainen M., Vilbaste J. (1976) Transition zone between two clines in Philaenus spumarius (L.) (Homoptera, Aphrophoridae). Annales Entomologici Fennici, 42(2): 105-111

Klimaszewski S.M., Kosonocka L. (1981) Intrapopulational colouring variations and hemolymph protein compositions in Philaenus spumarius L. (Homoptera, Cercopidae). Polskie Pismo Entomology, 51: 193-199

Lis A., Maryan'ska-Nadachowska A., Lachowska-Cierlik D., Kajtoch Ł. (2014) The secondary contact zone of phylogenetic lineages of the Philaenus spumarius (Hemiptera: Aphrophoridae): an example of incomplete allopatric speciation. Journal of Insect Science, 14: 227

Ossiannilsson F. (1981) The Auchenorrhyncha (Homoptera) of Fennoscandia and Denmark. Part 2: The families Cicadidae, Cercopidae, Membracidae, and Cicadellidae (excl. Deltocephalinae). Fauna Entomol. Scandinavica. V. 7. Part 2. Klampenborg, 593 p.

Quartau J.A., Borges P.A.V. (1997) On the colour polymorphism of Philaenus spumarius (L.) (Homoptera, Cercopidae) in Portugal. Misc. Zool., 20.2: 19-30

Raatikainen M. (1971) The polymorphism of Philaenus spumarius (L.) (Homoptera) in Northern Italy. Annales Entomologici Fennici, 37(1): 72-79

Rodrigues A.S.B., Silva S.E., Marabuto E., Silva D.N., Wilson M.R., Thompson V., Yurtsever S., Halkka A., Borges P.A.V., Quartau J.A., Paulo O.S., Seabra S.G. (2014) New mitochondrial and nuclear evidences support recent demographic expansion and an atypical phylogeographic pattern in the spittlebug Philaenus spumarius (Hemiptera, Aphrophoridae). PLOS One, 9(6): 1-12

Rodrigues A.S.B., Silva S.E., Pina-Martins F., Loureiro J., Castro M., Gharbi K., Johnson K.P., Dietrich Ch.H., Borges P.A.V., Quartau J.A., Jiggins Ch.D., Paulo O.S., Seabra S.G. (2016) Assessing 
genotype-phenotype associations in three dorsal colour morphs in the meadow spittlebug Philaenus spumarius (L.) (Hemiptera: Aphrophoridae) using genomic and transcriptomic resources. BMC Genetics, 17: 144

Seabra S.G., Pina-Martins F., Marabuto E., Yurtsever S., Halkka O., Quartau J.A., Paulo O.S. (2010) Molecular phylogeny and DNA barcoding in the meadow-spittlebug Philaenus spumarius (Hemiptera, Cercopidae) and its related species. Molecular Phylogenetic Evolution, 56(1): 462-467

Yurtsever S. (2000) On the polymorphic meadow spittlebug, Philaenus spumarius (L.) (Homoptera: Cercopidae). Turkish Journal of Zoology, 24: 447-459

Yurtsever S. (2004) Population genetics of Philaenus spumarius on Isntranca Mountains: polymorphism and phenotype frequency. Acta Zoologica Academiae Scientiarum Hungaricae, 50 (1): $25-34$ 